Int. J. Electrochem. Sci., 14 (2019) 8276 - 8283

\title{
A promising Modification of Pt Surfaces with CNTs for Decreasing Poisoning Impact in Direct Methanol Fuel Cells
}

\author{
Islam M. Al-Akraa*, Yaser M. Asal, Aya A. Khalifa \\ Department of Chemical Engineering, Faculty of Engineering, The British University in Egypt, Cairo \\ 11837, Egypt \\ *E-mail: islam.ahmed@ @ue.edu.eg, islam0886@yahoo.com
}

doi: $10.20964 / 2019.08 .116$

Received: 16 March 2019 / Accepted: 19 May 2019 / Published: 30 June 2019

Direct methanol fuel cells (DMFCs) are clean energy sources that have many applications due to the high energy density of methanol as a fuel. However, this type of fuel cells (FCs) has limitations that are preventing it from being commercialized. One such limitation is the adsorption of intermediates such as $\mathrm{CO}$ into the surface of the Platinum (Pt) catalyst during methanol oxidation (MO) which deactivates its active sites, where the reaction is taking place, and leads to poisoning of the electrode over the long term. In this study, multi-walled carbon nanotubes (MWCNTs) have been introduced to the Pt-modified glassy carbon (Pt/GC) electrode aiming to improve MO efficiency. The results showed that MWCNTs could help in enhancing the electrocatalytic activity of the modified electrode which reflected from increasing the direct oxidation current, $I_{\mathrm{p}}{ }^{\mathrm{d}}$, by a factor of 1.6. This increases the electrode' activity and durability during continuous electrolysis.

Keywords: Methanol oxidation; Fuel cells; Carbon nanotubes; Poisoning; Platinum.

\section{FULL TEXT}

(C) 2019 The Authors. Published by ESG (www.electrochemsci.org). This article is an open access article distributed under the terms and conditions of the Creative Commons Attribution license (http://creativecommons.org/licenses/by/4.0/). 